\title{
SOLE AND SEQUENTIAL APPLICATION OF HERBICIDE AND STRAW MULCH ON WEED GROWTH AND PRODUCTIVITY OF DIRECT SEEDED RAINFED RICE (ORYZA SATIVA L.)
}

\author{
PK Sangramsingh and Subhaprada Dash* \\ Department of Agronomy, Faculty of Agricultural Sciences, IAS, \\ Siksha 'O' Anusandhan, Deemed to be University, Bhubaneswar, Odisha \\ Keywords: Direct seeded, Rainfed rice, Herbicide, Mulching, Rice straw
}

\begin{abstract}
The sole and sequential application of herbicide and straw mulch on weed growth and productivity of rainfed direct seeded rice, were studied with 12 treatments during kharif 2019. Results showed that the application of oxadiargyl $f b$ rice straw mulch @ $6 \mathrm{t} / \mathrm{ha}$ registered significantly the lowest weed density and dry weight at 60 DAS; however, it was statistically at par with oxadiargyl $f b$ hand weeding. Weed free check produced the highest grain yield (3.05 t/ha) which was at par with the sequential application of oxadiargyl $f b$ rice straw mulch @ $6 \mathrm{t} / \mathrm{ha}(2.99 \mathrm{t} / \mathrm{ha})$ and oxadiargyl $f b$ rice hand weeding $(2.90 \mathrm{t} / \mathrm{ha})$. Application of oxadiargyl $f b$ rice straw mulch @ 6 t/ha fetched the maximum net return of Rs. 17528/- per ha and return per rupee invested of 1.52. Application of oxadiargyl $f b$ rice straw mulch @ $6 \mathrm{t} / \mathrm{ha}$ could be recommended for managing complex weed flora, higher productivity and greater profit in rainfed direct seeded rice cultivation.
\end{abstract}

\section{Introduction}

Rice is consumed as the staple food and more or less $90 \%$ of rice globally is cultivated by most of the Asian countries. The rice crop can be grown under different ecosystems with various methods associated to it. In overall rice growing areas, the direct seeded rice (DSR) has been familiarized among the farmers due to the saving of labour, water and energy. More specifically, in rainfed upland condition, the cultivation of direct seeded rice is gaining popularity in recent years. It also minimizes the methane emission, which is a major concern in transplanted rice worldwide. But in general, the productivity of DSR is not at all comparable with the transplanted rice. Out of several constraints of such low productivity, the vigorous and aggressive weed infestation is the important one. In DSR, the weed infestation can significantly reduce the yield to the tune of 50-91\% (Mathew et al. 2013). In some situation, when weed infestation is beyond the control of farmer throughout the crop growing period, then the weeds can cause a complete yield reduction. Thus, the comparable yield can be achieved from DSR by reducing the weeds below economic threshold level through different weed management practices.

Hand weeding is preferred by the farmers but it increases the cost of cultivation due to higher labour wages, whereas, its effectiveness for removal of weeds is not guaranteed during the critical period of crop weed competition. Therefore, the application of herbicide has gradually been used by replacing hand weeding or manual weed control. In these situations, low volume preemergence herbicides play a significant role in controlling the weeds and thereby enhancing the production. Most of the pre-emergence, early post emergence herbicides were applied in large quantities for weed management in direct seeded rice field. These herbicides are very effective for controlling weeds. The recent development of broad-spectrum herbicide provides an opportunity to control weeds in direct seeded rice. But sole application of herbicide may not be a viable option in sustainable agriculture. Use of herbicide alone is not at all an eco-friendly approach. Excess and

\footnotetext{
*Author for correspondence: 〈subhapradadash@soa.ac.in>.
} 
frequent use of particular herbicide may invite the herbicide resistance in weeds. The application of rice straw mulch is effective to control weeds in rice cultivation and it is quite environment friendly (Devasinghe et al. 2011). The density of grassy weeds is reduced in the mulched rice field at all stages of crop growth (Singh et al. 2007). Use of rice straw is the most effective way to have control over the problematic weed i.e., barnyard-grass (Echinochloa crusgalli (L.) Beauv.) in rice (Chung et al. 2003). It has been observed that no single method of weed control is effective and sustainable in the long run. Therefore, herbicidal application should be integrated with any other method of weed management in a judicious manner to attain better result in a safe way. Herbicidal application coupled with rice straw mulching would be beneficial in integrated plant management systems, while reducing the load of agrochemicals. This is an important concern in modern agriculture. Hence, the present investigation was undertaken to evaluate the efficacy of herbicide and straw mulch on weed growth, crop productivity and economics of rice.

\section{Materials and Methods}

Field experiment was carried out during kharif season of 2019-20 at the Agricultural Research Station, Binjhagiri, Chhatabar, IAS, SOADU, Bhubaneswar, Odisha, India. The farm is situated at about $20^{\circ} 15^{\prime} \mathrm{N}$ latitude and $85^{\circ} 40^{\prime} \mathrm{E}$ longitude with an altitude of $58 \mathrm{~m}$ above the MSL. The soil of the experimental plot was loamy in texture and acidic ( $\mathrm{pH} 5.82$ ) reaction, low in organic $\mathrm{C}$ $(0.48 \%)$, available $\mathrm{N}(206.8 \mathrm{~kg} / \mathrm{ha})$ and $\mathrm{K}(131.2 \mathrm{~kg} / \mathrm{ha})$, whereas, medium in available $\mathrm{P}(20.4$ $\mathrm{kg} / \mathrm{ha}$ ). The experiment was replicated thrice in randomized complete block design (RCBD) with 12 treatments. Herbicide spraying was done by using knap sack sprayer with flat fan nozzle with their respective doses at appropriate stages. Spray volume used for spraying herbicides was 500 liters per ha. for both pre-emergence and post-emergence herbicides. Hand weeding was done manually as per treatment. The air-dried rice straw of 'Samrat' from the previous crop was used as the mulch. Three days after seeding, the rice straw was spread in the inter-row space onto the soil surface at varying rate as per treatment. Rice variety 'Mandakini' was used at the seed rate of 75 $\mathrm{kg} / \mathrm{ha}$ with row to row spacing of $20 \mathrm{~cm}$ at a depth of $3 \mathrm{~cm}$. The crop was fertilized with $60 \mathrm{~kg} \mathrm{~N}$, $30 \mathrm{~kg} \mathrm{P}_{2} \mathrm{O}_{5}$ and $30 \mathrm{~kg} \mathrm{~K}_{2} \mathrm{O}$ per hectare through urea, SSP and MOP, respectively. The entire dose of phosphorus and potash along with $25 \% \mathrm{~N}$ was applied as basal. The remaining $\mathrm{N}$ was applied in two splits (50\% at tillering and 25\% at panicle initiation). The crop was harvested manually with sickle at a height of 5-7 cm from ground surface and threshed manually. The weeds of grasses, broadleaf and sedges weeds were recorded at 60 DAS by placing a quadrate of $50 \times 50 \mathrm{~cm}$ from the marked sampling area of $1.0 \mathrm{~m}^{2}$ in each plot. The phytosociological attributes of weed species were also recorded (Table 1). For recording their dry weight, weed samples were dried (sun drying followed by oven drying) at $65 \pm 5^{\circ} \mathrm{C}$ temperature until constant weight was attained. Grain and straw yield were taken from the undisturbed net plot area in the center of each plot and expressed in $\mathrm{kg} / \mathrm{ha}$ at $14 \%$ moisture. The yield attributing parameters were also recorded just before the harvesting. Net return and return per rupee invested were calculated using the minimum support price of rice and local market prices for other resources.

\section{Results and Discussion}

In the experimental field seven predominant weed species like Poа апnиа L., Digitaria sanguinalis (L.) Scop. and Echinochloa colona (L.) Link. among the grasses; Cyperus iria L. among the sedges, and Ludwigia parviflora Roxb., Melochia corchorifolia L. and Alternanthera philoxeroides (Mart.) Griseb. among the broadleaved weeds were observed throughout the crop growing period. The highest number of weed species ( $3 \mathrm{spp}$.) was found under Poaceae. Rest of the families consists of single species each. Absolute density, abundance and importance value 
were found highest at Ludwigia parviflora under Onagraceae (Table 1). Dash et al. (2016a, 2016b) also reported the dominance of Echinochloa sp., C. iria and A. philoxeroides in rice.

Table 1. The phytosociological attributes of weeds in direct seeded rainfed rice due to sole and sequential application of herbicides and straw mulch.

\begin{tabular}{|c|c|c|c|c|c|}
\hline Name of the weed & Family & $\begin{array}{l}\text { No. of treatment } \\
\text { they occurred }\end{array}$ & $\begin{array}{c}\text { Absolute } \\
\text { density }\end{array}$ & $\begin{array}{l}\text { Abund } \\
\text { ance }\end{array}$ & $\begin{array}{l}\text { Importance } \\
\text { value index }\end{array}$ \\
\hline Poa annua $\mathrm{L}$. & Poaceae & 11 & 7.25 & 7.91 & 45.95 \\
\hline Digitaria sanguinalis (L.) Scop. & Poaceae & 11 & 5.92 & 6.45 & 40.82 \\
\hline Echinochloa colona (L.) Link. & Poaceae & 08 & 3.83 & 5.75 & 30.26 \\
\hline Cyperus iria $\mathrm{L}$. & Cyperaceae & 10 & 6.58 & 7.90 & 42.83 \\
\hline Ludwigia parviflora Roxb. & Onagraceae & 09 & 9.58 & 12.78 & 55.18 \\
\hline Melochia corchorifolia $\mathrm{L}$. & Sterculiaceae & 07 & 6.92 & 11.86 & 44.66 \\
\hline $\begin{array}{l}\text { Alternanthera philoxeroides } \\
\text { (Mart.) Griseb. }\end{array}$ & Amaranthaceae & 05 & 5.50 & 13.20 & 40.31 \\
\hline
\end{tabular}

Among the weed management treatments, oxadiargyl $f b$ rice straw mulch @ 6 t/ha significantly minimized the density and biomass of all categories of weeds as well as total weeds at 60 DAS, which was statistically at par with the application of oxadiargyl $f b$ hand weeding (Table 2). This could be attributed to the integrated approach of pre-emergence herbicide followed by straw mulching or hand weeding had effective control of weed viz. grasses, sedges and broadleaved weeds. The next best treatment was oxadiargyl $f b$ rice straw mulch @ 4 t/ha, which was significantly followed by the application pendimethalin $f b$ rice straw mulch @ 6 t/ha and pendimethalin $f b$ hand weeding in reducing the density and biomass of grasses, broadleaved, sedges and total weeds at 60 DAS. Sole reliance on herbicidal application may bring about weed flora shifts as well as herbicide resistant weed biotypes (Shrestha et al. 2010). Such problems can be managed by an integrating appropriate herbicide with viable weed management options such as mulching and/or hand weeding (Maity and Mukherjee 2008). Among the herbicidal treatments, sole application of oxadiargyl was found to remain superior to pendimethalin application, in keeping the total weed biomass under suppression (Table 2). As oxadiargyl is a selective, preemergence herbicide and ensures effective control of weeds, it is active by contact action with emerging or recently emerged shoots coming in contact with treated soil particles. Broadleaved weeds, grasses, and sedges together accumulated the highest total biomass at 60 DAS under weedy check and their contributions to the total weed biomass were in the proportion of 61.15 , 32.56 and $6.29 \%$, respectively (Table 2).

It is revealed from Table 3 that the highest panicle weight, panicle number $/ \mathrm{m}^{2}$, number of grains/panicles were documented in weed free treatment, which remained statistically at par with oxadiargyl $f b$ rice straw mulch @ 6 t/ha and oxadiargyl $f b$ rice hand weeding. All the yield attributes were numerically and significantly less in weedy check plots of DSR during kharif season. According to Ibni Zamir et al. (2014), there was significant effect in application of straw mulch on cobs per plant, grain rows per cob, 1000-grain weight, grain yield, biological yield and stalk yield of maize.

The highest productivity of grain $(3.05 \mathrm{t} / \mathrm{ha})$ and straw (3.90 t/ha) was found to be significant under the weed free treatment, which, however, was found to maintain statistically similar yield levels with oxadiargyl $f b$ rice straw mulch @ $6 \mathrm{t} / \mathrm{ha}\left(2.99 \mathrm{t}\right.$ grain $\mathrm{ha}^{-1}$ and $3.78 \mathrm{t}$ straw/ha) and oxadiargyl $f b$ rice hand weeding $(2.90 \mathrm{t}$ grain/ha and $3.73 \mathrm{t}$ straw/ha) (Table 3). Mulching maintained optimum soil temperature and enhanced organic matter in soil and ultimately improved 


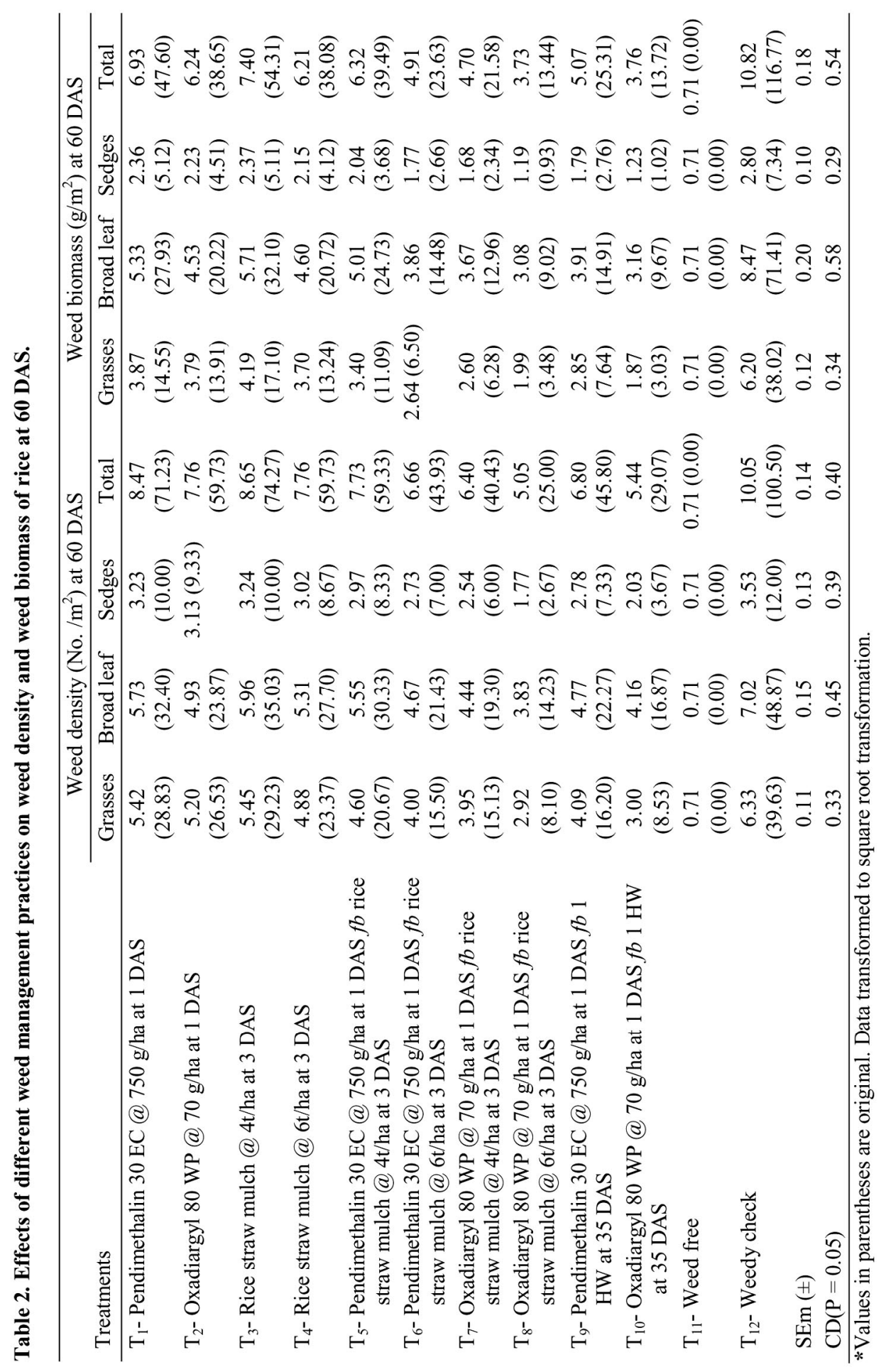




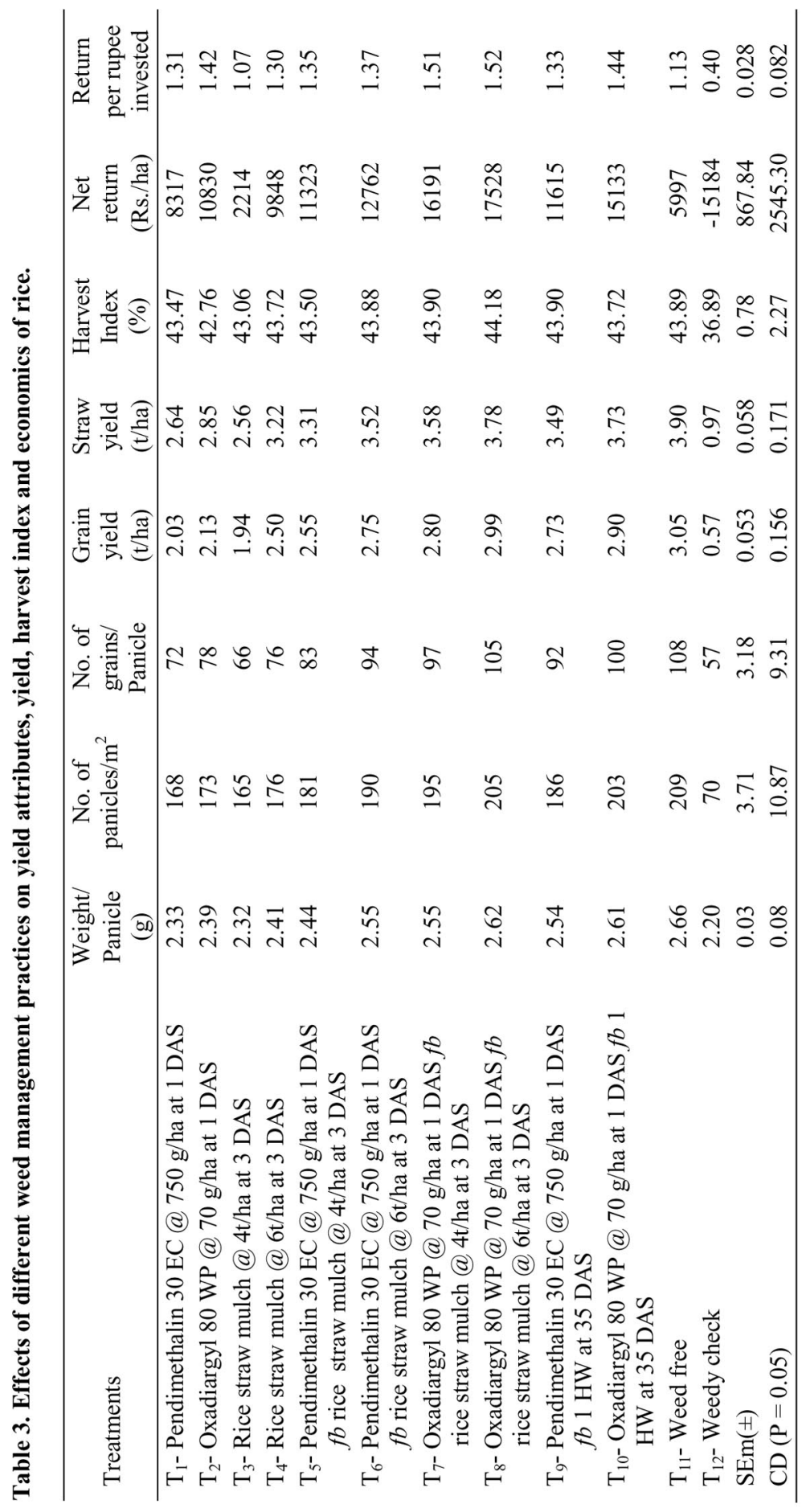


growth, yield and quality of the crop by reducing the weed infestation (Bhardwaj 2013). Compared with weedy check, yield advantages under these treatments ranged from 80.35 to $81.32 \%$ and 73.87 to $74.99 \%$, on grain and straw yield, respectively. Addition of mulching reduced seedling emergence of several weed species, but the quantities of mulching played a vital role in causing substantial reduction in weed densities (Singh et al. 2007). In the present study, the next better treatments viz. oxadiargyl $f b$ rice straw mulch @ $4 \mathrm{t} / \mathrm{ha}$, pendimethalin $f b$ rice straw mulch @ 6 t/ha and pendimethalin $f b$ hand weeding were comparable in registering higher levels of grain and straw productivity, respectively. The weedy check plot always remained inferior in terms of productivity levels. The grain yield was inversely correlated with increasing weed biomass and weed density in rainfed upland rice. Except the weedy check plot, all the weed management treatments were significantly at par with each other in respect of harvest index (HI). The highest HI was recorded under oxadiargyl $f b$ rice straw mulch @ 6 t/ha followed by oxadiargyl $f b$ rice straw mulch @ 4 t/ha, pendimethalin $f b$ hand weeding and weed free treatment during kharif season (Table 3).

Net returns from kharif rice cultivation were significantly influenced by the weed management practices. Among weed management treatments, oxadiargyl $f b$ rice straw mulch @ 6 t/ha fetched the highest net return (Rs. 17,528/- per ha) and return per rupee invested (1.52). It was remained at par with oxadiargyl $f b$ rice straw mulch @ $4 \mathrm{t} / \mathrm{ha}$ (net return Rs. 16,191/- per ha and return per rupee invested 1.51) and oxadiargyl $f b$ hand weeding (net return Rs. 15,133/- per ha and return per rupee invested 1.44) (Table 3). More or less similar results of increasing net returns and B : C ratio of maize due to application of straw mulching was observed by Kumar (2015).

From the results of the present study, the sequential application of oxadiargyl 80 WP @ 70 $\mathrm{g} / \mathrm{ha}$ at 1 DAS $f b$ rice straw mulch @ 6 t/ha at 3 DAS may be recommended for managing complex weed flora, obtaining higher yield and greater profit of direct seeded rice cultivation.

\section{References}

Bhardwaj RL 2013. Effect of mulching on crop production under rainfed condition- a review, Agricul. Rev. 34(3): 188-197.

Chung IM, Kim KH, Ahn JK, Lee SB, Kim SH and Hahn SJ 2003. Comparison of allelopathic potential of rice leaves, straw, and hull extracts on barnyard-grass. Agro. J. 95: 1063-1070.

Dash S, Malik GC, Banerjee M, Sethi D 2016 a. Weed management in summer rice and their residual effect on blackgram. Int. J. Farm Sci. 6(2): 19-23.

Dash S, Malik GC, Banerjee M, Sethi D 2016 b. Effect of different weed management practices in Boro rice cultivation. Adv. Life Sci. 5(4): 1351-1355.

Devasinghe D, Premarathne K and Sangakkara U 2011. Weed Management by Rice Straw Mulching in Direct Seeded Lowland Rice (Oryza sativa L.). Trop. Agric. Res. 22(3): 263-272.

Ibni Zamir S, Asif M, Ihtishamulhaq, Ashraf U, Hussain S and Khan MK 2014. Maize phenology, yield and its quality is affected by organic mulches and various irrigation regimes. Inter. J. Modern Agric. 2(3): 56-59.

Kumar R 2015. Productivity, profitability and nutrient uptake of maize (Zea mays) as influenced by management practices in North-East India. Indian J. Agron. 60(2): 273-278.

Maity SK and Mukherjee PK 2008. Integrated weed management in dry direct seeded rainy season rice. Indian J. Agron. 53(2): 116-120.

Mathew R, Raj SK, Jose N and Leenakumary S 2013. Comparative efficacy of penoxsulam and pyrazosulfuron ethyl for weed control in direct seeded puddle rice (Oryza sativa). Indian J. Agricul. Sci. 83(12): 1420-1422. 
Shrestha A, Hanson BD, Fidelibus MW and Alcorta M 2010. Growth, phenology and intraspecific competition between glyphosate-resistant and glyphosate-susceptible horseweeds in the San Joaquin vally of California. Weed Sci. 58(2): 147-153.

Singh S, Ladha JK, Gupta RK, Bhusan L, Rao AN, Sivaprasad B and Singh PP 2007. Evaluation of mulching, intercropping with Sesbania and herbicide use for weed management in dry-seeded rice (Oryza sativa). Crop Protect. 26: 518-524.

(Manuscript received on 14 August, 2020; revised on 26 March, 2021) 